\section{OAK RIDGE$$
Y-12
$$$$
\text { PLANT }
$$

MARTIN MARUETRA \\ IRIDIUM ALLOY CLAD VENT SET \\ MANUFACTURING QUALIFICATION STUDIES
}

G. B. Ulrich

Materials Engineering Department Development Division

Date of Issue: June 15, 1990

Prepared for submission to:

8th Symposium on Space Nuclear Power Systems Presented by

The Institute for Space Nuclear Power Studies Chemical/Nuclear Engineering Department University of New Mexico

Albuquerque, New Mexico 87131
OPERATED BY

MARTIN MARIETTA ENERGY SYSTEMS, INC.

FOA THE UNITED STATES

DEPARTMENT OF ENERGY
Prepared by the

Oak Ridge Y-12 Plant

Oak Ridge, Tennessee 37831 operated by MARTIN MARIETTA ENERGY SYSTEMS, INC. for the U.S. DEPARTMENT OF ENERGY under contract DE-AC05-84OR21400 


\section{DISCLAIMER}

This report was prepared as an account of work sponsored by an agency of the United States Government. Neither the United States Government nor any agency Thereof, nor any of their employees, makes any warranty, express or implied, or assumes any legal liability or responsibility for the accuracy, completeness, or usefulness of any information, apparatus, product, or process disclosed, or represents that its use would not infringe privately owned rights. Reference herein to any specific commercial product, process, or service by trade name, trademark, manufacturer, or otherwise does not necessarily constitute or imply its endorsement, recommendation, or favoring by the United States Government or any agency thereof. The views and opinions of authors expressed herein do not necessarily state or reflect those of the United States Government or any agency thereof. 


\section{DISCLAIMER}

Portions of this document may be illegible in electronic image products. Images are produced from the best available original document. 
This report was prepared as an account of work sponsored by an agency of the United States Government. Neither the United States Government nor any agency thereof, nor any of their employees, makes any werranty, express or implied, or assumes any logal liability or responsibility for the accuracy, completeness, or usefulness of any information, apparatus, product, or process disclosed, or represents that its use would not infringe privately owned rights. Reference herein to any specific commercial product, process, or service by trade name. trademark. manufacturer, or othermse, does not necessarily constitute or imply its endorsement, recommendation, or fevoring by the United States Government or any agency thereof. The views and opinions of authors expressed herein do not necessarily state or reflect those of the United States Government or any agency thereof.

COPYRIGHT NOTICE

BY ACCEPTANCE OF THIS ARTICLE, THE PUBLISHER AND/OR RECIPIENT ACKNOWLEDGES THE U. $S$. GOVERNMENT'S RIGHT TO RETAIN A NONEXCLUSIVE ROYALTY-FREE LICENSE IN AND TO ANY COPYRIGHT COVERING THIS PAPER.

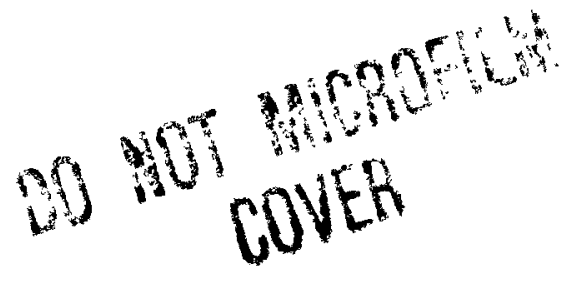




\title{
IRIDIUM ALLOY CLAD VENT SET MANUFACTURING QUALIFICATION STUDIES
}

\author{
George B. Ulrich \\ Martin Marietta Energy Systems, Inc. \\ Oak Ridge Y-12 Plant \\ P.O. Box 2009 \\ Oak Ridge, TN 37831-8096 \\ 615-574-1243
}

Y/DV--977-Draft

DE91 009316

\section{DRAFT}

\section{INTRODUCTION}

In 1987 the Department of Energy-Office of Special Applications (DOE-OSA) decided to transfer the iridium alloy Clad Vent Set (CVS) manufacturing for the General Purpose Heat Source (GPHS) program from EG\&G Mound Applied Technologies, Inc. (EG\&G-MAT) to the Oak Ridge Y-12 Plant operated by Martin Marietta Energy Systems, Inc. (Energy Systems). The reason for this transfer was to consolidate the GPHS program iridium hardware manufacturing. The CVS starting stock of iridium powder, foil, and blanks were already being manufactured at another Energy Systems facility - the Oak Ridge National Laboratory (ORNL).

Since 1987 CVS manufacturing technology transfer efforts have taken place between EG\&G-MAT and Energy Systems. EG\&G-MAT retained all of their tooling, but they supplied all the necessary product drawings, specifications, and procedures, as well as their tooling drawings. Most of the tooling designs and processing steps were duplicated at the Y-12 Plant. Minor changes were required in both tooling design and processing steps, to accommodate particular health, safety, environmental, and manufacturing requirements at the Y-12 Plant.

In order to evaluate the effects of the key Y-12 Plant processing modifications, four joint Y-12 Plant/EG\&G-MAT iridium CVS manufacturing qualification studies were organized. The successful completion of these studies allowed the Y-12 Plant to commence pilot production of CVS components for the CRAF and CASSINI missions. The CVS cup metallurgical qualification work will be presented here.

\section{METHODS}

The cup metallurgical comparisons consisted of evaluating porosity and inclusion contents, grain size and microstructural attributes, and microhardness of both the Y-12 Plant and EG\&G-MAT products. Initially, the Y-12 Plant product was four new process (vacuum arc remelted, extruded, and rolled) and one old process (arc cast and rolled) iridium alloy, DOP-26, nonflight quality cups. These cups were recrystallized for one hour at $1573^{\circ} \mathrm{K}$ in vacuum $(1.3 \mathrm{x}$ $10^{-2} \mathrm{~Pa}$ or better). This was performed in a Y-12 Plant Development Division furnace because the new Y-12 Plant production high temperature vacuum furnaces were not available at the time. The EG\&G-MAT product was five old process, flight quality cups recrystallized using the same parameters described above. The EG\&G-MAT cups were also outgassed for one hour at $1773^{\circ} \mathrm{K}$ in vacuum. The Y-12 Plant cups were not outgassed because both Energy Systems and EG\&G-MAT personnel concurred that the $1773^{\circ} \mathrm{K}$ outgassing step was probably unnecessary or

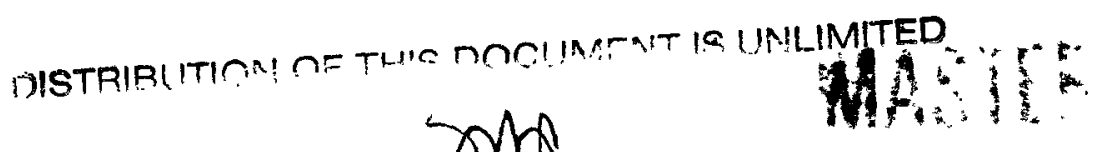


at least excessive (with regard to temperature). It should be noted that an optional $1498^{\circ} \mathrm{K}$ outgassing step has been retained in the Y-12 Plant assembly operations.

The cups were electrical discharge machined (EDM) into 12 equal pole-to-equator sections at each facility. Each section was sequentially numbered from 1 to 12 as it was machined. The EDM edges were mechanically removed by sanding. Cup sections 2 and 8 were metallographically prepared and analyzed at the Y-12 Plant, while sections 1 and 7 were prepared and analyzed at EG\&G-MAT. The remaining sections were used for other qualification studies.

Microhardness readings were taken at EG\&G-MAT using their standard $200 \mathrm{~g}$ test load. All samples tested at the Y-12 Plant were tested at both $200 \mathrm{~g}$ and $1000 \mathrm{~g}$ test loads. This was done with the intent to qualify the $1000 \mathrm{~g}$ test load for production use.

All the results from the analyses at each site were compared. These comparisons indicated that follow-up work was required to achieve full recrystallization in non-outgassed new process material. It was also evident that additional microhardness testing was required because of the use of an improperly calibrated microhardness tester at the Y-12 Plant. This follow-up work was conducted at the Y-12 Plant on new process material recrystallized for one hour at $1648^{\circ} \mathrm{K}$ in one of the new production high temperature vacuum furnaces.

Before any of these follow-up heat treat runs were made one of the new production vacuum furnaces was zone certified. The zone certification was conducted at $1648^{\circ} \mathrm{K}$ using eight thermocouples. Three of these thermocouples were the regular furnace thermocouples arranged at different heights. One of each of the five auxiliary thermocouples were placed in the corners and center of the hearth. Five tungsten weights were used to hold the thermocouples in position and to serve as heat treat mass simulators. During the zone certification the furnace thermocouples ranged from 1646 to $1649^{\circ} \mathrm{K}$ while the auxiliary hearth thermocouples ranged from 1656 to $1660^{\circ} \mathrm{K}$. The five hearth thermocouples were approximately $10^{\circ} \mathrm{K}$ hotter because of their proximity to the bottom furnace elements. The cup heat treat procedure calls for 1648 $\pm 25^{\circ} \mathrm{K}$; therefore, these minor gradients were deemed acceptable.

Once the zone certification was successfully completed, three additional heat treat runs were made with new process cups (for destructive testing) as well as scrap cups used to simulate the effects of a full heat treat group. The first additional heat treat run was made with three new process cups (from blanks E1-5-1, 2, and 3) and twenty-five scrap cups. All of these cups were placed on and covered with graphite felt. The second heat treat run was made with two new process cups (from blanks E1-10-6 and -7) and 22 scrap cups. This run was made using a tantalum box and cover lined on the inside bottom with graphite felt. The reason for using the tantalum box was to minimize the use of graphite felt in the high temperature vacuum furnace in order to better protect the iridium and the furnace itself from potential contamination.

All five of the new process cups from the first two additional heat treat runs were EDMed into sections. Six sections from each cup were evaluated for extent of recrystallization and grain size only. Since all five cups were found to be fully recrystallized, the third and final follow-up heat treat run was made with three new process cups (from blanks D1-10-4, CR3-13-1 and -6) and 33 scrap cups. This run was also made using the tantalum box and cover lined on the inside bottom with graphite felt. The two blanks from the CR3 ingot were intentionally chosen as material produced using the most recent blank processing improvements (primarily improved 
vacuum arc remelting/extrusion/rolling practices). Again, after heat treating the three cups were EDMed into sections. Six sections from each cup were given a full metallurgical evaluation to determine how well they conformed to the metallography requirements of Energy Systems specification, GPHS-M-188, Revision B (equivalent to EG\&G-MAT's SPA790433, Revision E). These requirements are listed below.

\section{Metallography Requirements - GPHS-M-188, Revision B}

Hardness. Microhardness of the fully heat-treated cup shall be between 250 and 350 diamond pyramid hardness (DPH). This test shall be performed with a diamond pyramid indentor at the load of $1000 \mathrm{~g}$ according to ASTM E 92-82. The averages of three hardness values normal to the centerline shall be taken at the pole, radius, and equator of at least two sample sections. The hardness shall be taken on unetched surfaces of mounted sections.

Microstructure. Grain size of the fully heat-treated cup shall not exceed ASTM grain size 3, and any internal defects shall be kept within acceptable limits as specified in the following table.

\section{POROSITY}

No single void

greater than 10 microns.

Maximum concentration

of porosity shall not

exceed the level grouping

shown in ASTM B276-79, $\mathrm{AO} 2$.

\section{INCLUSIONS}

There shall be no continuous stringer longer than $0.25 \mathrm{~mm}$.

The combined length of all continuous stringers and individual inclusion in any $6.4 \mathrm{~mm}$ length of a sample shall not exceed a length of $0.4 \mathrm{~mm}$. Use ASTM E45-81 for method.

There shall be no cracks or laminations.

The microstructure of entire cross-sectional area of the four sections shall be examined. Any anomalous metallurgical conditions shall be noted and photographed.

\section{RESULTS AND DISCUSSION}

The comparison evaluations done on the sections from the five cups produced by each facility indicated excellent agreement with regard to porosity and inclusion contents. There were no out-of-specification conditions noted for any of these ten cups nor for the three follow-up cups that were also evaluated for internal defects.

The evaluations for grain size and microstructural attributes such as elongated or duplex grain structure and cracks or delaminations were also in excellent agreement. As stated previously the new process material did not fully recrystallize at $1573^{\circ} \mathrm{K}$ (see Figure 1 ). This is consistent with earlier work at EG\&G-MAT (Forrest et al. 1986). Figure 2 shows that new process material heat treated at $1648^{\circ} \mathrm{K}$, but not outgassed, does fully recrystallize. Table 1 shows that material in this condition has the same or slightly finer grain size than any of the other material conditions. 
There were no consistent grain size patterns evident with regard to cup location/orientation within the Y-12 Plant production furnace nor in relation to position (pole, radius, or equator) within sections. Cracks or delaminations were found only in some of the non-flight quality original study material.

The Y-12 microhardness data from the original four cups made at the Y-12 Plant from new process material are not included in Table 1 because of (1) the previously mentioned microhardness tester calibration problems and (2) the inhomogeneous microstructure from incomplete recrystallization. The valid microhardness ranges shown in Table 1 indicate that the new process material tends to be slightly harder than the old process material. The microhardness differences between loads at specific positions (same cup and same position) ranged from 24 to $106 \mathrm{DPH}$, but they were typically around $60 \mathrm{DPH}$. The $1000 \mathrm{~g}$ test load always produced lower values. This is consistent with earlier unpublished findings by $\mathrm{T}$. $\mathrm{K}$ Roche at ORNL and is best explained by the high elastic modulus, approximately $517 \mathrm{GPa}$, for iridium.

A statistical analysis was performed on both sets of microhardness data $(200 \mathrm{~g}$ and $1000 \mathrm{~g}$ test load) from the last 18 cup sections. There were no statistically significant differences found among cups or locations using the $200 \mathrm{~g}$ test load. The overall average was $341 \pm 78$ DPH (3 sigma limits). This implies limits of 260 to $420 \mathrm{DPH}$ versus the present specification of 250 to $350 \mathrm{DPH}$. Based on the present specification limits, $36 \%$ of the reported positional (pole, radius, or equator) averages would be expected to be outside the specification limits.

Using the $1000 \mathrm{~g}$ test load there were no statistical differences in microhardness among the cups; however, there were some minor differences between locations. The poles averaged $289 \pm 49$ (3 sigma limits) versus $272 \pm 40 \mathrm{DPH}$ at the radius and $272 \pm 47 \mathrm{DPH}$ at the equator. The overall average was $278 \pm 50 \mathrm{DPH}$. This implies limits of 230 to $330 \mathrm{DPH}$. Based on the present specification limits, $5 \%$ of the positional averages would be expected to be outside the specification limits. The $1000 \mathrm{~g}$ load tended to reduce the variability in the data compared to the $200 \mathrm{~g}$ load because of the reduced elastic modulus effects, as well as the increased operator ease in reading the indentations.

\section{CONCLUSIONS}

The initial Y-12 Plant and EG\&G-MAT cup metallurgical comparisons in conjunction with the Y-12 Plant follow-up work has confirmed/established agreement between the Y-12 Plant and EG\&G-MAT on the specified cup metallurgical criteria. Energy Systems and EG\&G-MAT personnel concurred that the use of a $1000 \mathrm{~g}$ test load for microhardness testing will be acceptable for the iridium CVS cups. Additional $1000 \mathrm{~g}$ test load data will be collected and analyzed to determine whether or not the microhardness requirements should be modified. The Y-12 Plant iridium CVS manufacturing processes are now considered fully qualified.

\section{$\underline{\text { Reference }}$}

Mary A. Forest, James R. McDougal, and Ranny W. Saylor, General Purpose Heat Source (GPHS), Clad Vent Set (CVS) Formability Study, MLM-3395, Monsanto Research Corporation, Mound Facility, Miamisburg, Ohio (November 1986). 


\section{Acknowledgements}

The Oak Ridge Y-12 Plant is operated by Martin Marietta Energy Systems, Inc., for the U.S. Department of Energy under contract DE-AC05-84OR21400.

The author would like to thank R. W. Saylor for his efforts in coordinating this study at EG\&G-MAT. Thanks also go to L. F. Deroos for the metallography work and M. W. Sherrill for the statistical analyses at the Y-12 Plant. 


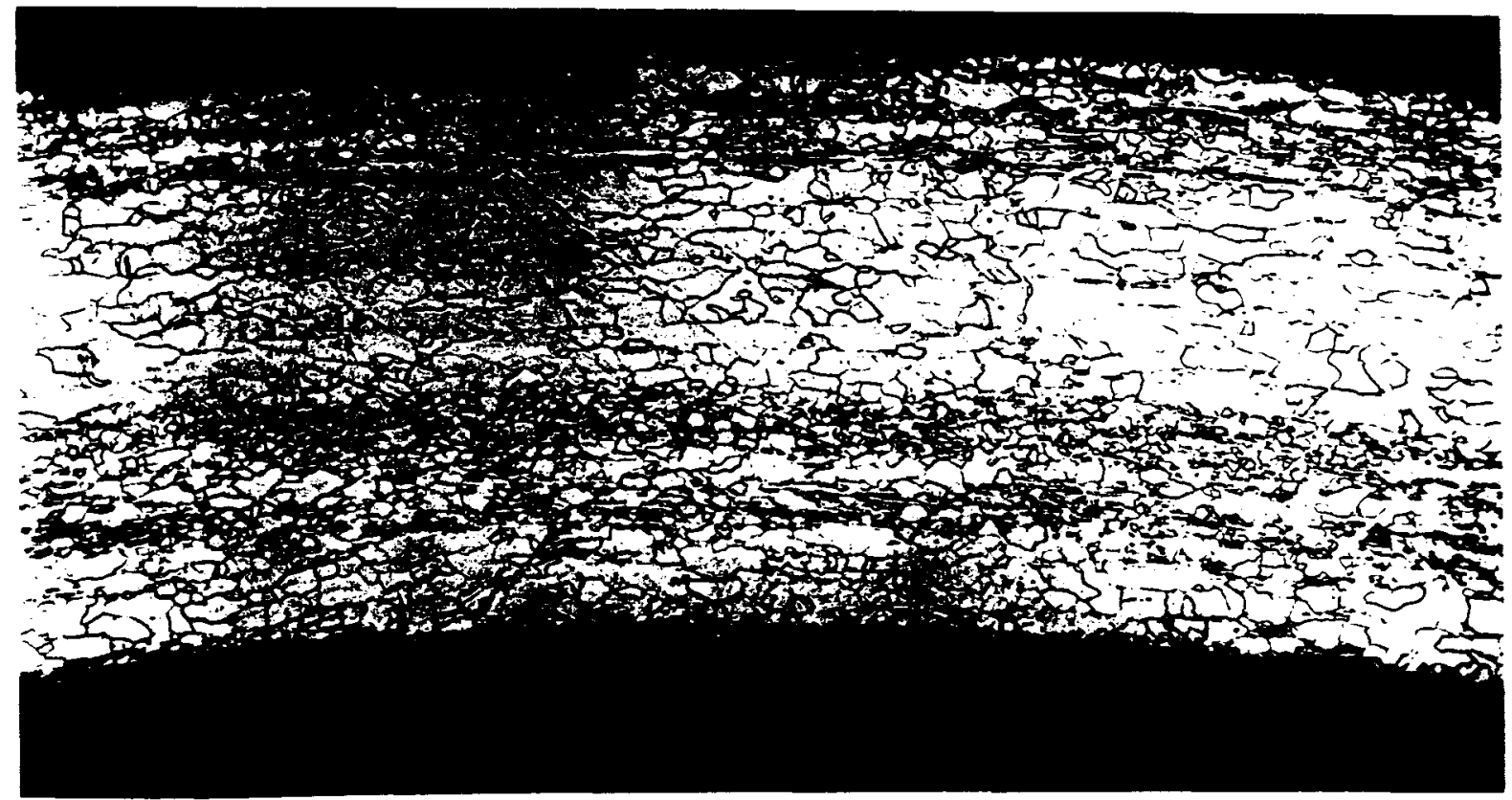

Figure 1. PN 3792-14-3460-2 from Work Request 5628 (blank BR6-8--5)

Incomplete recrystallization in radius region of cup

formed from new process material. Recrystallized at $1573^{\circ} \mathrm{K}$ for 1 hour - not outgassed. Magnification $100 \mathrm{X}$.

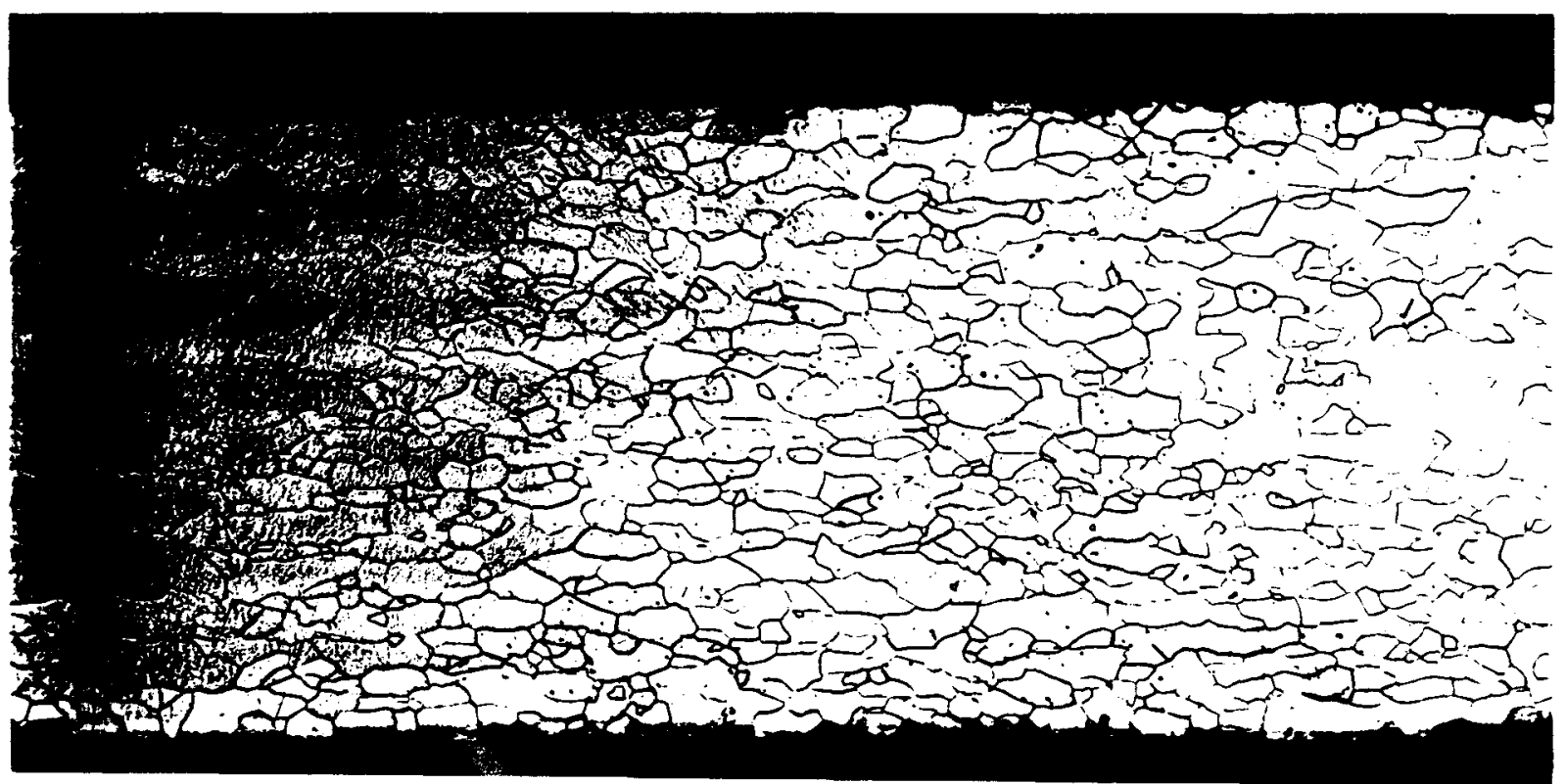

Figure 2. PN 3886-40-1494-7 from Work Request 5628 (blank CR3-13-1)

Typical microstructure in polar region of cup formed from improved new process material. Recrystallizated at $1648^{\circ} \mathrm{K}$ for 1 hour -

not outgassed. ASTM 7 Magnification 100X. 
Table 1. Microstructuctural Data for Various Material/Test Conditions

\begin{tabular}{|c|c|c|c|c|c|c|c|}
\hline \multirow[t]{2}{*}{$\begin{array}{c}\text { Blank } \\
\text { Process }\end{array}$} & \multirow[t]{2}{*}{$\stackrel{\text { Cup }}{\text { Fabrication Facility }}$} & \multirow[t]{2}{*}{$\begin{array}{l}\text { Heat Treat } \\
\text { Condition }\left({ }^{\circ} \mathrm{K}\right)\end{array}$} & \multirow[t]{2}{*}{$\begin{array}{l}\text { Testing } \\
\text { Facility }\end{array}$} & \multicolumn{2}{|c|}{$\begin{array}{l}\text { ASTM Grain } \\
\text { Size Number }\end{array}$} & \multirow{2}{*}{\multicolumn{2}{|c|}{$\begin{array}{c}\text { Vickers } \\
\text { Microhardness (DPH) } \\
200 \text { g Load } 1000 \text { g Load }\end{array}$}} \\
\hline & & & & Range & Average & & \\
\hline Old & EG\&G - MAT & $1573 / 1773$ & EG\&G - MAT & $-\cdots$ & --- & $294-349$ & --- \\
\hline Old* & EG\&G - MAT & $1573 / 1773$ & EG\&G - MAT & -- & 7 & $251-337$ & --- \\
\hline Old & EG\&G - MAT & $1573 / 1773$ & Y-12 Plant & $5-1 / 2-6-1 / 2$ & 6 & --- & --- \\
\hline Old & Y-12 Plant & 1573 & EG\&G - MAT & $6-1 / 2-7$ & $6-1 / 2$ & $307-333$ & -- \\
\hline New* & EG\&G - MAT & $1573 / 1773$ & EG\&G - MAT & -- & 7 & $286-366$ & --- \\
\hline New* & EG\&G - MAT & 1573 & EG\&G - MAT & NFR** & 7 & $306-391$ & $-\cdots$ \\
\hline New & Y-12 Plant & 1573 & EG\&G - MAT & $\mathrm{NFR}^{* *}$ & $6-1 / 2-9$ & $304-357$ & --- \\
\hline New & Y-12 Plant & 1648 & Y-12 Plant & $6-1 / 2-7-1 / 2$ & $7+$ & $291-403$ & $252-318$ \\
\hline
\end{tabular}

* Data from Forrest et al. 1986.

** NFR - Not fully recrystallized. 


\section{Distribution:}

University of New Mexico

Mohamed S. El-Genk, Technical Chairman (4)

EG\&G Mound Applied Technologies, Inc.

Wayne R. Amos

Ranny W. Saylor

Teledyne Energy Systems

Paul J. Dick

Oak Ridge National Laboratory

M. M. Martin

E. K. Ohriner

U. S. Department of Energy

Office of Special Applications

W. J. Barnett

Y-12 Plant

L. F. Deroos W. E.Keyes (2)

W. G. Northcutt, Jr./T. H. Thrasher

C. R. Riggs

M. W. Sherrill

G. B. Ulrich

9202 File Point

Central Files - RC

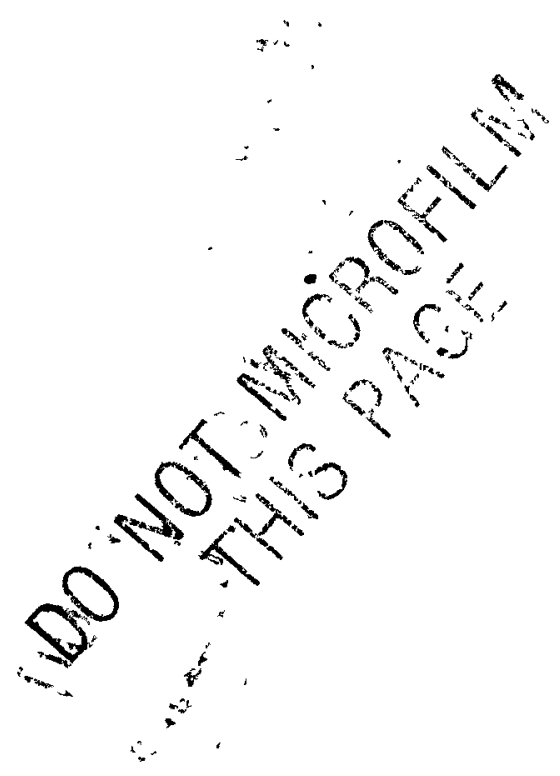

